\title{
Influence of Cover Crops and Irrigation Rates on Tomato Yields and Quality in a Subtropical Region
}

Qingren Wang, Waldemar Klassen, Yuncong Li, ${ }^{1}$ and Merlyn Codallo Tropical Research and Education Center, University of Florida, Homestead, FL 33031

\author{
Aref A. Abdul-Baki \\ Agricultural Research Service, U.S. Department of Agriculture, Beltsville, \\ MD 20705
}

\section{Additional index words. cowpea, soil N, sorghum sudangrass, sunn hemp, velvetbean}

\begin{abstract}
Intensive rainfall during summer causes substantial nutrient leaching in a subtropical region, where most vegetable lands lay fallow during this period. Also, an excessive amount of irrigation water supplied during the winter vegetable growing season leads to soil nutrient loss, which greatly impacts vegetable yields, especially in soils that possess a low capacity to retain soil water and nutrients. A 2-year field experiment was carried out to evaluate the effects of various summer cover crops and irrigation rates on tomato yields and quality, and on soil fertility in a subtropical region of Florida. The cover crops were sunn hemp [Crotalaria juncea (L.) 'Tropic Sun'], cowpea [Vigna unguiculata (L.) Walp, 'Iron Clay'], velvetbean [Mucuna deeringiana (Bort.) Merr.], and sorghum sudangrass [Sorghum bicolor $\times S$. bicolor var. sudanense (Piper) Stapf.], with a weed-free fallow as a control. The cover crops were planted during late Spring 2001 and 2002, incorporated into the soil in the fall, and tomatoes [Lycopersicon esculentum (Mill.) 'Sanibel'] were grown on raised beds during Winter 2001-02 and 2002-03, respectively. Irrigation in various treatments was controlled when tensiometer readings reached $-5,-10,-20$, or $-30 \mathrm{kPa}$. The cover crops produced from 5.2 to $12.5 \mathrm{Mg} \cdot \mathrm{ha}^{-1}$ of above ground dry biomass and 48 to $356 \mathrm{Mg} \cdot \mathrm{ha}^{-1}$ of $\mathrm{N}$ during 2001-02 and from 3.6 to $9.7 \mathrm{Mg} \cdot \mathrm{ha}^{-1}$ of dry biomass and 35 to $277 \mathrm{~kg} \cdot \mathrm{ha}^{-1}$ of $\mathrm{N}$ during 2002-03. The highest $N$ contribution was made by sunn hemp and the lowest by sorghum sudangrass. Based on 2-year data, tomato marketable yields were increased from $14 \%$ to $27 \%(p \leq 0.05)$ by growing cover crops, and the greatest increase occurred in the sunn hemp treatment followed by the cowpea treatment. Irrigation at $-10,-20$, and $-30 \mathrm{kPa}$ significantly improved marketable yields by $14 \%, 12 \%$, and $25 \%(p \leq 0.05)$ for $2001-02$, and $18 \%, 31 \%$, and $34 \%(p \leq 0.05)$ for $2002-03$, respectively, compared to yields at the commonly applied rate, $-5 \mathrm{kPa}$ (control). Irrigation at $-30 \mathrm{kPa}$ used about $85 \%$ less water than at $-5 \mathrm{kPa}$. Yields of extra-large fruit in the sunn hemp and cowpea treatments from the first harvest in both years averaged 12.6 to $15.2 \mathrm{Mg} \cdot \mathrm{ha}^{-1}$, and they were significantly higher than yields in the fallow treatment $\left(10.2\right.$ to $\left.11.3 \mathrm{Mg} \cdot \mathrm{ha}^{-1}\right)$. Likewise at $-30 \mathrm{kPa}$ yields of extra-large fruit from the first harvest for both years were 13.0 to $15.3 \mathrm{Mg} \cdot \mathrm{ha}^{-1}$ compared

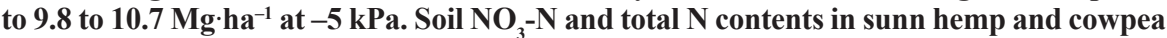
treatments were significantly higher than those in fallow. The results indicate that growing legume summer cover crops in a subtropical region, especially sunn hemp and cowpea, and reducing irrigation rates are valuable approaches to conserve soil nutrients and water, and to improve soil fertility and tomato yields and quality.
\end{abstract}

Soil nutrient conservation is a great concern in designing sustainable agriculture programs, especially in tropical and subtropical regions. These regions receive large amounts of mostly torrential rainfall during the annual rainy season(s), which can cause intensive soil nutrient loss via leaching and erosion. In the subtropical region of southern Florida, the average annual rainfall is $1,499 \mathrm{~mm}$ and ranges

\footnotetext{
Received for publication 9 June 2005. Accepted for publication 1 Aug. 2005. We thank USDA-ARS and Florida Tomato Committee for their financial support with Specific Cooperative Agreement No. 58-1265-1-034, CSREES, USDA Project Award No. 2001-51102-11325. The manuscript has been approved for publication as Florida Agricultural Experiment Station journal series R-10972.

${ }^{1}$ To whom reprint requests should be addressed; e-mailyunli@ifas.ufl.edu.
}

1987), and a major threat to nutrient-poor marine and terrestrial ecosystems. Nitrate leaching is worsened by keeping the land fallow (Campbell etal., 1984, 1994), and by improper soil and crop management practices (Hallberg, 1989; Linville and Smith, 1971).

Some summer cover crops have proven able to reduce soil water and nutrient loss, since cover crops can scavenge soil nutrients and accumulate them in plant tissues as a nutrient pool to be used by subsequent crops (Brandi-Dohrn et al., 1997; Karlen and Doran, 1991; Wang et al., 2005). Cover crops may also improve soil structure, reduce soil erosion, conserve soil moisture, and suppress plant-parasitic nematodes and other damaging organisms (Wang et al., 2002b).

Most soils used for vegetable production in the subtropical region of southern Florida have been developed from the limestone bedrock by means of rock plows, which break up the surface layer of the bedrock to produce a coarse soil. The latter is prone to nutrient leaching because of its high gravel and low organic matter contents. On these coarse soils growers produce tomatoes and other high value vegetables during the dry winter months, and either leave their land fallow or grow sorghum sudangrass as a conventional summer cover crop during the rainy summer months.

The use of leguminous cover crops to maintain, or improve, the nitrogen status of soil can reduce dependence on commercial $\mathrm{N}$-fertilizers in crop production, and contribute to energy conservation (Abdul-Baki et al., 1997). Nevertheless, the performance of various summer leguminous cover crops needs to be evaluated in southern Florida with respect to adaptation to subtropical conditions, growth rates, duration from seeding to flowering, biomass production, performance in high $\mathrm{pH}$ calcareous soils, $\mathrm{N}$ fixation, resistance to plant parasitic nematodes, especially root-knot nematodes (Meloidogyne spp.) and effectiveness in suppression of weeds (Li et al., 1999).

The main objectives of this experiment were to 1) compare the effects of four summer cover crops (legumes $=$ sunn hemp, cowpea, and velvetbean and nonlegumes $=$ sorghum sudangrass) on subsequent tomato crop yield, 2) determine the optimum irrigation rate for tomato growth and yield in a subtropical region, and 3) evaluate soil nutrient contents that result from growing cover crops and use of different irrigation regimes.

\section{Materials and Methods}

Site description of field experiments. The experimental site is located at the Tropical Research and Education Center, University of Florida, Homestead. The soil is a Krome very gravelly loam (loamy-skeletal, carbonatic, hyperthermic Lithic Udorthents). The soil contains $58.8 \%$ gravel ( $>2 \mathrm{~mm}$ ), particle distributions of the soil are $48.4 \%$ sand, $30.3 \%$ silt, and $21.3 \%$ clay. Soil $\mathrm{CaCO}_{3}$ is $25 \%$ to $36 \%$, organic $\mathrm{C}$ is 17.8 to $26.2 \mathrm{~g} \cdot \mathrm{kg}^{-1}$, total $\mathrm{N}$ is 1.1 to $1.8 \mathrm{~g} \cdot \mathrm{kg}^{-1}$, and the soil $\mathrm{pH}$ is 7.6 to 7.8 .

Experimental design and management. A randomized split-plot design, replicated four- 
times, was used with cover crops as main plots, and irrigation rates as subplots. Each cover crop was planted into a main plot on a bed, i.e., sunn hemp [Crotalariajuncea (L.) 'Tropic Sun], cowpea [Vigna unguiculata (L.) Walp. 'Iron Clay], velvetbean [Mucuna deeringiana (Bort.) Merr.], sorghum sudangrass [Sorghum bicolor $\times S$. bicolor var. sudanense (Piper) Stapf], and a weed-free fallow was maintained as a control. In April 2001, the field was disked and raised beds, $15 \mathrm{~cm}$ high and $91 \mathrm{~cm}$ wide, on $182 \mathrm{~cm}$ between centers were formed. The experiment was repeated at the same site with same treatments beginning in the spring of 2002. Each plot consisted of an 11-m long section of the bed containing $20 \mathrm{~m}^{2}$. Seeding rates for cowpea, velvetbean, sunn hemp and sorghum sudangrass were $112,34,56$, and 56 $\mathrm{kg} \cdot \mathrm{ha}^{-1}$, respectively. All legume seeds were coated with the Rhizobium 'EL' cowpea inoculant (Nitragin Inoculants, Liphatech, Inc., Milwaukee, Wis.) immediately before planting. The cover crops were seeded on 9 May 2001 and 26 July 2002 with a Tye no-till drill (AGCO Corp., Lawrenceville, Ga.). In midJuly 2001, above-ground biomass samples of cowpea were collected to obtain biomass dry weight, and plants were flail-mowed at ground level to avoid maturation because cowpea only requires a 2-month growth period. Cowpea residues were left on the surface of plots, and those plots were reseeded with cowpea. Also, in mid-July 2001, the sunn hemp was mowed 30$\mathrm{cm}$ above ground to destroy the plant's apical dominance, induce more branches (Abdul-Baki et al., 2001), and avoid formation of fibrous stems that decompose slowly. Sunn hemp biomass samples from $30-\mathrm{cm}$ above ground were collected before mowing to obtain the dry weight produced, and the residues were left on the surface of the plots. In 2002-03, the cover crops could not be seeded until 26 July 2002, and only one crop of cowpea was grown. Sunn hemp plants were again mowed at $30-\mathrm{cm}$ above ground on 27 Sept. 2002. Each year an aboveground biomass sample of each cover crop was taken from a $0.5 \mathrm{~m}^{2}$ area immediately before the cover crop was terminated by flail-mowing. Cover crops were terminated on 1 Oct. 2001 and 25 Nov. 2002, respectively, and the residues incorporated by rototilling about 1 week after mowing. In October 2001 and November 2002, dry fertilizer $\left(6 \mathrm{~N}-6 \mathrm{P}_{2} \mathrm{O}_{5}-12 \mathrm{~K}_{2} \mathrm{O}\right)$, at the rate of 1,123 $\mathrm{kg} \cdot \mathrm{ha}^{-1}$, was banded at $25-\mathrm{cm}$ on each side of the bed center, and rototilled into the soil. The beds were reformed, and two drip lines and whiteon-black plastic mulch (Helena Chemical Company, Collierville, Tenn.) were installed on all beds. Tomato [Lycopersicon esculentum (Mill.) 'Sanibel'] seedlings were transplanted into beds in a single row with $50-\mathrm{cm}$ between plants. Transplanting was done on 23 Oct. 2001 and on 9 Dec. 2002. Atensiometer was installed in each bed, and drip lines were attached to a layflat hose with individual valves installed to allow the irrigation of beds to achieve soil moisture tensions of $-5,-10,-20$, or $-30 \mathrm{kPa}$. Based on tensiometer readings taken daily between 9 and 10:30 AM valves were opened manually to provide irrigation at each of the above rates. Practices to control foliar insects and diseases were applied according to Maynard and Olson (2000). Starting with the sixth liquid fertilizer consisting of $4 \mathrm{~N}-\mathrm{OP}_{2} \mathrm{O}_{5}-8 \mathrm{~K}_{2} \mathrm{O}$ was delivered through the drip lines once a week until the second harvest.

Sampling and analysis. Soil $(0$ to $10 \mathrm{~cm})$ samples were collected immediately before tomato seedlings were transplanted and at flowering. Tomato leaf tissue samples were collected at flowering for nutrient analysis. Dry weights were determined on the aboveground biomass of each cover crop just before termination, and for tomato plants at flowering. For tomato tissue nutrient analysis the third fully expanded leaf from the top was taken from each of 5 randomly selected plants in each plot before whole plants were collected for aboveground dry biomass determination.

Soil samples were air dried for over two weeks and plant samples oven dried at $70{ }^{\circ} \mathrm{C}$ for $>72 \mathrm{~h}$. The samples were ground to pass through a $<2-\mathrm{mm}$ mesh sieve for soil, and $1-\mathrm{mm}$ mesh sieve for plant tissues. Soil samples were analyzed for total $\mathrm{N}$ using a Vario Max CNS Auto-analyzer(Elementar, Hanau, Germany). Subsamples were held at $500{ }^{\circ} \mathrm{C}$ for $12 \mathrm{~h}$ in a muffle furnace to obtain their organic carbon content based on the weight loss-on-ignition (WLOI) method (Schulte and Hopkins, 1996; Jolivet et al., 1998). Other sub-samples were extracted with ammonium bicarbonate-diethylene triaminepentaacetic acid (AB-DTPA), and inductively coupled plasma-optical emission spectroscopy (ICP-OES, Ultima 2C, Horiba, Jobin Yvon, Inc., Edison, N.J.) was used to determine other plant available macro- and micronutrients (Hanlon et al., 1996). Soil $\mathrm{NO}_{3}-\mathrm{N}$ and $\mathrm{NH}_{4}-\mathrm{N}$ were analyzed with an autoanalyzer (model-3; Bran Luebbe, Norderstedt, Germany) after extraction with $2 \mathrm{~N}$ $\mathrm{KCl}$. The CNS autoanalyzer (Elementar) was used to determine $\mathrm{N}$ and $\mathrm{C}$ in soil and plants samples ground to pass through a $<2-\mathrm{mm}$ sieve. Tomato fruit sugar concentration and titratable acidity were determined at the first harvest from 5 randomly selected large, mature red fruits from each plot by the method described by Stevens et al. (1979).

Harvest and grading. Tomatoes were harvested three times in both years. The first harvest was performed when about $10 \%$ of fruit had turned red, and only red or yellow, large, and extra large fruit were harvested during this time. Two weeks later the second harvest was conducted in a similar manner. week after tomato transplanting, $328 \mathrm{~L} \cdot \mathrm{ha}^{-1}$ of

After yet another 2 weeks, the third harvest was carried out and it included all fruits except those smaller than medium size. Harvested fruit was graded according to the Florida Tomato Committee Standards (Brown, 2000), i.e., fruits from each harvest were separated into extra-large, large, and medium grades, and nonmarketable culls.

Statistics. The data were subjected to ANOVA and means were separated using Duncan's multiple range test in the SAS program (SAS institute, 1999). Both linear regression analysis with trending line options for scatter data distribution, and correlation analysis between two data sets were performed with the Excel system.

\section{Results}

Above-ground cover crop biomass. In 2001-02, all three legume cover crops produced significantly more biomass than did sorghum sudangrass, but in 2002-03, only sunn hemp and velvetbean produced significantly more biomass than did sorghum sudangrass, while cowpea produced only about as much biomass as sorghum sudangrass (Table 1). Average N concentrations in the biomass of sunn hemp, cowpea, and velvetbean were $2.85 \%, 2.08 \%$, $2.58 \%$, respectively, and higher than that in sorghum sudangrass, which was $0.92 \%$ (Table 1). The amounts of $\mathrm{N}$ potentially contributed to the soil by sunn hemp, cowpea, velvetbean, and sorghum sudangrass were 277 to 356,75 to 243 , 173 to 286 , and 35 to $48 \mathrm{~kg} \cdot \mathrm{ha}^{-1}$, respectively (Table 1). With C contents ranging from $38 \%$ to $43 \%$ of dry weight in the plant tissues of given cover crops (data not shown), the total quantity of organic $\mathrm{C}$ returned into the soil ranged from 1.5 to $5.3 \mathrm{Mg} \cdot \mathrm{ha}^{-1}$.

Amounts of irrigation water applied at the various soilmoisture tensions. In 2002-03 only about one half of the amount of irrigation water was applied to the tomato crop as applied in 2001-02 (Table 2). However, with the quantity of water applied at $-5 \mathrm{kPa}$ as the basis of comparison, the percentages of irrigation water saved when irrigated at $-30 \mathrm{kPa}$ in these 2 years were quite similar, i.e., $85.6 \%$ during 2002-03 and $84.5 \%$ during 2001-02 (Table 2).

Tomato yield and quality as affected by cover crop and irrigation rate. Cover crop treatments and irrigation rates affected the total marketable yields of tomatoes significantly, but there was no significant interaction between cover crop treatments and irrigation rates (Table 3). Total tomato marketable yields, and yields

Table 1. Above ground biomass produced and total $\mathrm{N}$ contents returned into the soil of cover crops in 2001-02 and 2002-03.

\begin{tabular}{lccccc}
\hline \multirow{2}{*}{$\begin{array}{l}\text { Cover } \\
\text { crop }\end{array}$} & $\begin{array}{c}\text { Biomass } \\
\left(\mathrm{Mg} \cdot \mathrm{ha}^{-1}\right)\end{array}$ & \begin{tabular}{c}
$\mathrm{N}$ \\
\cline { 5 - 6 }$\left(\mathrm{kg} \cdot \mathrm{ha}^{-1}\right)$
\end{tabular} & & $\begin{array}{c}\text { Biomass } \\
\left(\mathrm{Mg} \cdot \mathrm{ha}^{-1}\right)\end{array}$ & $\begin{array}{c}\mathrm{N} \\
\left(\mathrm{kg} \cdot \mathrm{ha}^{-1}\right)\end{array}$ \\
\hline Sunn hemp & $12.5 \mathrm{a}^{\mathrm{z}}$ & $356 \mathrm{a}^{\mathrm{y}}$ & & $9.7 \mathrm{a}$ & $277 \mathrm{a}$ \\
Cowpea & $11.7 \mathrm{~b}$ & $243 \mathrm{~b}$ & & $3.6 \mathrm{bc}$ & $75 \mathrm{bc}$ \\
Velvetbean & $11.1 \mathrm{~b}$ & $286 \mathrm{ab}$ & & $6.7 \mathrm{ab}$ & $173 \mathrm{ab}$ \\
Sorghum sudangrass & $5.2 \mathrm{c}$ & $48 \mathrm{c}$ & & $3.8 \mathrm{c}$ & $35 \mathrm{c}$ \\
\hline
\end{tabular}

${ }^{\mathrm{z}}$ Values within a column followed by the same letter are not significantly different $(p \leq 0.05, \mathrm{n}=16)$, Duncan's multiple range tests.

${ }^{y} \mathrm{~N}$ concentrations in various cover crops determined were sunn hemp $=2.85 \%$, cowpea $=2.08 \%$, velvetbean $=2.58 \%$, and sorghum sudangrass $=0.92 \%$. 
Table 2. Amounts $\left(\mathrm{m}^{3}\right)$ of irrigation water applied to tomatoes irrigated at different soil moisturebased irrigation rates.

\begin{tabular}{lrr}
\hline Irrigation regime & $2001-02$ & $2002-03$ \\
\hline$-30 \mathrm{kPa}$ & $386 \mathrm{c}^{\mathrm{z}}$ & $185 \mathrm{~b}$ \\
$-20 \mathrm{kPa}$ & $463 \mathrm{bc}$ & $206 \mathrm{~b}$ \\
$-10 \mathrm{kPa}$ & $592 \mathrm{~b}$ & $234 \mathrm{~b}$ \\
$-5 \mathrm{kPa}$ & $2,487 \mathrm{a}$ & $1,289 \mathrm{a}$ \\
Year $\times$ irrigation regime & \multicolumn{2}{c}{ NS } \\
\hline
\end{tabular}

${ }^{z}$ Values within a column followed by the same letter are not significantly different $(p \leq 0.05, \mathrm{n}=16)$ and NS means no significant difference, Duncan's multiple range tests.

of extra large fruit, were significantly higher with all cover crop treatments than with fallow in 2001-02, but only with sunn hemp and cowpea treatments in 2002-03 (Table 4). In 2001-02, the cover crops increased tomato total marketable fruit yields by 18 to $27 \%$, and yields of extra large fruit by $35 \%$ to $46 \%$ compared to the fallow treatment. In 2002-03, the sunn hemp and cowpea treatments increased total marketable fruit yields by $14 \%$ and yields of extra large fruits by $13 \%$ to $22 \%$, respectively, compared to the fallow treatment.

The reduction of irrigation rates from the control $(-5 \mathrm{kPa})$ increased total marketable yields in both years, which resulted in significantly higher yields of the total marketable, extra large and large fruit (Table 4). The marketable yields at $-30 \mathrm{kPa}$ in both years were 55 and 53.6 $\mathrm{Mg} \cdot \mathrm{ha}^{-1}$, which were $25 \%$ greater in 2001-02 and $34 \%$ greater in 2002-03 than those at -5 $\mathrm{kPa}\left(44\right.$ and $\left.40 \mathrm{Mg} \cdot \mathrm{ha}^{-1}\right)$. Similarly irrigation at $-30 \mathrm{kPa}$ increased yields of extra-large fruit from 26.9 to $32.6 \mathrm{Mg} \cdot \mathrm{ha}^{-1}$ in 2001-02, and 22.6 to $28.9 \mathrm{Mg} \cdot \mathrm{ha}^{-1}$ in $2002-03$, which were $21 \%$ and $28 \%$, respectively, and it increased yields of large fruit from 14.6 to $18.6 \mathrm{Mg} \cdot \mathrm{ha}^{-1}$ in $2001-02$,

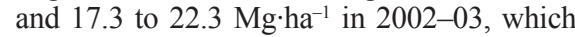
were $27 \%$ and $29 \%$, respectively, compared to those at $-5 \mathrm{kPa}$ (Table 4).

Yields from the first harvest are presented

Table 3. Summary of the ANOVA for tomato total marketable yields with cover crop treatment, irrigation rate and interaction between these two variables.

\begin{tabular}{lrcccc}
\hline Source & df & Sum of squares & Mean square & F value & $P>\mathrm{F}$ \\
\hline Cover crop & 4 & 944.534 & 236.134 & 3.87 & 0.0052 \\
Irrigation rate & 3 & $3,196.428$ & $1,065.476$ & 17.46 & $<0.001$ \\
Cover crop $\times$ irrigation & 12 & 746.331 & 62.194 & 1.02 & 0.435 \\
Replication & 3 & 336.164 & 122.055 & 2.00 & 0.117 \\
Year & 1 & 69.261 & 69.261 & 1.14 & 0.289 \\
\hline
\end{tabular}

in Table 5. Compared to the fallow treatment, the first harvest total marketable fruit yields from the sunn hemp and cowpea treatments were increased from $15.4 \mathrm{Mg} \cdot \mathrm{ha}^{-1}$ to over 19 $\mathrm{Mg} \cdot \mathrm{ha}^{-1}$ in 2001-02, which were higher by $24 \%$ and $29 \%$, respectively, and similarly in $2002-03$, by $18 \%$ for both treatments. Likewise the yields of extra-large fruit from the sunn hemp and cowpea treatments compared to the fallow increased by $35 \%$ and $28 \%$ in $2001-02$, respectively, and by $24 \%$ for both treatments in 2002-03.

Irrigation rates also significantly influenced tomato marketable yields and fruit quality in the first harvest. In 2001-02, the first harvest yields of total marketable fruit were $45 \%$, $37 \%$ and $22 \%$ greater at $-30 \mathrm{kPa},-20 \mathrm{kPa}$ and $-10 \mathrm{kPa}$, respectively, than at $-5 \mathrm{kPa}$. In 2002-03, the yield of total marketable fruit was $30 \%$ greater at $-30 \mathrm{kPa}$ than at $-5 \mathrm{kPa}$, but the apparent increases at $-20 \mathrm{kPA}$ and -10 kPA were not significant statistically (Table 5). It is worth noting that irrigation at $-30 \mathrm{kPa}$ in 2001-02 increased yields of total marketable fruit, extra-large fruit and large fruit in the first harvest by 45,43 and $55 \%$, respectively, and by 30,33 and $27 \%$, respectively, in 2002-03 compared to yields at $-5 \mathrm{kPa}$ (Table 5). Significant increases in yields of all grades of marketable fruits of the 1st harvest were also observed at $-20 \mathrm{kPa}$ and in some grades at $-10 \mathrm{kPa}$ in 2001-02, and for extra large fruits in 2002-03. For example in 2001-02, yields at $-20 \mathrm{kPa}$ vs. $-5 \mathrm{kPa}$ for total marketable, extra large and large fruit were 19.0 vs. 13.9 $\mathrm{Mg} \cdot \mathrm{ha}^{-1}, 14.0$ vs. $10.7 \mathrm{Mg} \cdot \mathrm{ha}^{-1}$ and 4.9 vs. 3.1 $\mathrm{Mg} \cdot \mathrm{ha}^{-1}$, respectively. In 2002-03, yields at -20 $\mathrm{kPa} v$ s. $-5 \mathrm{kPa}$ for extra large fruit were 11.3 vs. $9.8 \mathrm{Mg} \cdot \mathrm{ha}^{-1}$. Also at $-10 \mathrm{kPa}$ vs. $-5 \mathrm{kPa}$, yields of extra-large fruit in 2002-03 and large fruit in 2001-02 were significantly increased from 9.8 to 11.3 and from 3.1 to $5.0 \mathrm{Mg} \cdot \mathrm{ha}^{-1}$, respectively (Table 5).
Table 4. Tomato total marketable yields and yields of three different grades from all harvests as affected by cover crops and irrigation rates in each year of the two-year experiment.

\begin{tabular}{|c|c|c|c|c|c|c|c|c|}
\hline \multirow{2}{*}{$\begin{array}{l}\text { Parameter } \\
\text { Cover crop }\end{array}$} & \multicolumn{2}{|c|}{$\begin{array}{c}\text { Total } \\
\text { marketable } \\
\text { fruit yield }\end{array}$} & \multicolumn{6}{|c|}{ Fruit yields in various grades $\left(\mathrm{Mg} \cdot \mathrm{ha}^{-1}\right)$} \\
\hline & $2001-02$ & $2002-03$ & $2001-02$ & $2002-03$ & $2001-02$ & $2002-03$ & $2001-02$ & $2002-03$ \\
\hline Cowpea & $52.9 \mathrm{a}$ & $51.5 \mathrm{a}$ & $35.2 \mathrm{a}$ & $28.7 \mathrm{a}$ & $13.4 \mathrm{a}$ & $15.8 \mathrm{a}$ & $3.3 \mathrm{ab}$ & $7.0 \mathrm{a}$ \\
\hline Velvetbean & $49.7 \mathrm{a}$ & $47.7 \mathrm{ab}$ & $32.9 \mathrm{a}$ & $25.5 \mathrm{bc}$ & $13.4 \mathrm{a}$ & $14.8 \mathrm{a}$ & $3.4 \mathrm{a}$ & $7.4 \mathrm{a}$ \\
\hline Sorghum-sudangrass & $49.9 \mathrm{a}$ & $48.4 \mathrm{ab}$ & $32.5 \mathrm{a}$ & $25.9 \mathrm{bc}$ & $14.2 \mathrm{a}$ & $15.2 \mathrm{a}$ & $3.2 \mathrm{ab}$ & $7.3 \mathrm{a}$ \\
\hline Fallow & $42.0 \mathrm{~b}$ & $45.3 \mathrm{~b}$ & $26.8 \mathrm{~b}$ & $23.5 \mathrm{c}$ & $12.6 \mathrm{a}$ & $15.5 \mathrm{a}$ & $2.6 \mathrm{~b}$ & $6.3 \mathrm{a}$ \\
\hline$-20 \mathrm{kPa}$ & $49.1 \mathrm{~b}$ & $52.3 \mathrm{a}$ & $29.5 \mathrm{ab}$ & $27.9 \mathrm{ab}$ & $18.1 \mathrm{a}$ & $19.9 \mathrm{~b}$ & $3.1 \mathrm{a}$ & $4.5 \mathrm{a}$ \\
\hline$-10 \mathrm{kPa}$ & $50.2 \mathrm{ab}$ & $47.2 \mathrm{~b}$ & $28.3 \mathrm{ab}$ & $26.2 \mathrm{~b}$ & $18.8 \mathrm{a}$ & $19.5 \mathrm{bc}$ & $3.1 \mathrm{a}$ & $1.5 \mathrm{bc}$ \\
\hline$-5 \mathrm{kPa}$ & $44.0 \mathrm{c}$ & $40.0 \mathrm{c}$ & $26.9 \mathrm{~b}$ & $22.6 \mathrm{c}$ & $14.6 \mathrm{~b}$ & $17.3 \mathrm{c}$ & $2.5 \mathrm{a}$ & $0.1 \mathrm{c}$ \\
\hline
\end{tabular}

${ }^{2}$ Values within a column followed by the same letter for either cover crop or irrigation rate are not significantly different $(p \leq 0.05, \mathrm{n}=20$ for cover crops and $\mathrm{n}$ $=16$ for irrigation rates).

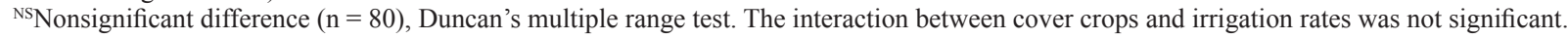

HortScience Vol. 40(7) December 2005
Effects of cover crops and irrigation rates taken at tomato transplanting, and at tomato flowering, indicated that at both dates the various cover crops generally increased the soil $\mathrm{N}$ content compared to that in the fallow treatment (control) (Table 6). In all cover crop treatments soil $\mathrm{NO}_{3}-\mathrm{N}$ concentrations were significantly greater than in the fallow treatment at transplanting and flowering in 2001-02, and also at flowering in 2002-03. However, only sunn hemp and cowpea showed a significantly higher concentration of $\mathrm{NO}_{3}-\mathrm{N}$ at both transplanting and flowering in both years (Table 6).

Soil concentrations of $\mathrm{NH}_{4}-\mathrm{N}$ were significantly increased by the sunn hemp treatment by the time of transplanting in both years, In the at flowering in 2002-03 over fallow. $\mathrm{NH}_{4}-\mathrm{N}$ was significantly increased by the time of transplanting in 2002-03. The velvetbean treatment failed to increase soil concentrations of $\mathrm{NH}_{4}-\mathrm{N}$ at any time in either year. The sorghum sudangrass treatment significantly increased soil concentrations of $\mathrm{NH}_{4}-\mathrm{N}$ only

(Table 6 ). at transplanting and at flowering by all cover crop treatments in both years with the exception of the sorghum sudangrass at transplanting in 2002-03 (Table 6). Soil total N concentrations transplanting and flowering were significantly greater than those in fallow, e.g., $0.197 \%$ vs. $0.136 \%$, and $0.242 \%$ vs. $0.160 \%$, respectively, and also in 2002-03, soil total N concentra. $0.203 \%$ Vs. $0.126 \%$, and $0.236 \%$ vs. $0.146 \%$ (Table 6 ), which were increases of $61 \%$ and $62 \%$, respectively. The corresponding soil 6). Moreover in both years, the concentrations of soil $\mathrm{NO}_{3}-\mathrm{N}$ and total $\mathrm{N}$ were increased between transplanting and flowering, and this may be related to the decomposition of cover crop residues. In this experiment, was a close correlation between the soil yields (Fig. 1).

Irrigation rates strongly influenced soil total $\mathrm{N}, \mathrm{NH}_{4}-\mathrm{N}_{\text {and }} \mathrm{NO}_{3}-\mathrm{N}$ concentrations (Fig. 2) so that at flowering a highly negative correlation $34 \%, 42 \%, 57 \%$, and $47 \%$, respectively (Table

HORTSCIENCE VOL. 40(7) DECEMBER 2005 
$(r \geq 0.90, p<0.01)$ between irrigation rates $(-5$, $-10,-20$ and $-30 \mathrm{kPa}$ ) and $\mathrm{N}$ concentration was observed. At the lowest irrigation rate, $-30 \mathrm{kPa}$, the concentrations of soil extractable $\mathrm{K}, \mathrm{Ca}, \mathrm{Mg}$, and Mo tended to be higher than at higher irrigation rate, i.e., $-5 \mathrm{kPa}$ (Table 7)

Table 5. Tomato total marketable yields and yields of three different grades from the first harvest as affected by cover crops and irrigation rates.

\begin{tabular}{|c|c|c|c|c|c|c|}
\hline \multirow[b]{3}{*}{ Parameter } & \multicolumn{6}{|c|}{ Yield $\left(\mathrm{Mg} \cdot \mathrm{ha}^{-1}\right)$} \\
\hline & \multicolumn{2}{|c|}{$\begin{array}{l}\text { Total marketable fruit } \\
\text { (1st harvest) }\end{array}$} & \multicolumn{2}{|c|}{$\begin{array}{l}\text { Extra-large fruit } \\
\text { (1st harvest) }\end{array}$} & \multicolumn{2}{|c|}{$\begin{array}{l}\text { Large fruit } \\
\text { (1st harvest) }\end{array}$} \\
\hline & $2001-02$ & $2002-03$ & $2001-02$ & $2002-03$ & $2001-02$ & $2002-03$ \\
\hline \multicolumn{7}{|l|}{ Cover crop } \\
\hline Sunn hemp & $19.9 \mathrm{a}^{\mathrm{z}}$ & $18.1 \mathrm{a}$ & $15.2 \mathrm{a}$ & $12.6 \mathrm{a}$ & $3.8 \mathrm{a}$ & $5.1 \mathrm{a}$ \\
\hline Cowpea & $19.1 \mathrm{a}$ & $18.0 \mathrm{a}$ & $14.5 \mathrm{ab}$ & $12.6 \mathrm{a}$ & $3.4 \mathrm{a}$ & $5.1 \mathrm{a}$ \\
\hline Velvetbean & $16.4 \mathrm{bc}$ & $15.3 \mathrm{~b}$ & $12.2 \mathrm{bc}$ & $10.6 \mathrm{~b}$ & $3.2 \mathrm{a}$ & $4.4 \mathrm{a}$ \\
\hline Sorghum-sudangrass & $16.5 \mathrm{bc}$ & $16.2 \mathrm{ab}$ & $11.9 \mathrm{c}$ & $10.8 \mathrm{~b}$ & $3.7 \mathrm{a}$ & $4.9 \mathrm{a}$ \\
\hline Fallow & $15.4 \mathrm{c}$ & $15.3 \mathrm{~b}$ & $11.3 \mathrm{c}$ & $10.2 \mathrm{~b}$ & $2.7 \mathrm{a}$ & $4.6 \mathrm{a}$ \\
\hline \multicolumn{7}{|l|}{ Irrigation rate } \\
\hline$-30 \mathrm{kPa}$ & $20.1 \mathrm{a}$ & $19.0 \mathrm{a}$ & $15.3 \mathrm{a}$ & $13.0 \mathrm{a}$ & $4.8 \mathrm{a}$ & $5.6 \mathrm{a}$ \\
\hline$-20 \mathrm{kPa}$ & $19.0 \mathrm{ab}$ & $16.4 \mathrm{bc}$ & $14.0 \mathrm{ab}$ & $11.3 \mathrm{~b}$ & $4.9 \mathrm{a}$ & $4.7 \mathrm{a}$ \\
\hline$-10 \mathrm{kPa}$ & $17.0 \mathrm{~b}$ & $16.3 \mathrm{bc}$ & $12.0 \mathrm{bc}$ & $11.3 \mathrm{~b}$ & $5.0 \mathrm{a}$ & $4.6 \mathrm{a}$ \\
\hline$-5 \mathrm{kPa}$ & $13.9 \mathrm{c}$ & $14.6 \mathrm{c}$ & $10.7 \mathrm{c}$ & $9.8 \mathrm{c}$ & $3.1 \mathrm{~b}$ & $4.4 \mathrm{a}$ \\
\hline
\end{tabular}

${ }^{2}$ Values within a column followed by the same letter for either cover crop or irrigation rate are not significantly different ( $p \leq 0.05, \mathrm{n}=20$ for cover crops and $\mathrm{n}=16$ for irrigation rates).

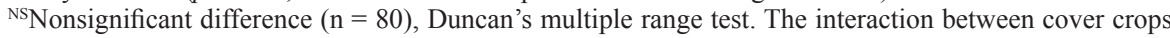
and irrigation rates was nonsignificant.

Table 6. Soil nitrogen concentrations just before transplanting, and during flowering, of tomatoes in plots with various cover crop treatments and fallow as a control.

\begin{tabular}{lccccr}
\hline Parameter & Sunn hemp & Cowpea & Velvetbean & Sorghum-sudangrass & Fallow \\
\hline $\mathrm{NO}_{3}-\mathrm{N}\left(\mathrm{mg} \cdot \mathrm{kg}^{-1}\right)$ & & & & & \\
Transplanting (2001-02) & $9.99 \mathrm{a}^{2}$ & $9.06 \mathrm{a}$ & $7.06 \mathrm{~b}$ & $6.86 \mathrm{~b}$ & $4.85 \mathrm{c}$ \\
Flowering (2001-02) & $26.35 \mathrm{a}$ & $24.72 \mathrm{ab}$ & $22.76 \mathrm{~b}$ & $18.75 \mathrm{c}$ & $15.06 \mathrm{~d}$ \\
Transplanting (2002-03) & $10.18 \mathrm{a}$ & $8.66 \mathrm{~b}$ & $6.45 \mathrm{bc}$ & $5.23 \mathrm{c}$ & $5.42 \mathrm{c}$ \\
$\quad$ Flowering (2002-03) & $25.67 \mathrm{a}$ & $23.48 \mathrm{~b}$ & $20.66 \mathrm{c}$ & $19.26 \mathrm{c}$ & $16.83 \mathrm{~d}$ \\
$\mathrm{NH}_{4}-\mathrm{N}\left(\mathrm{mg} \cdot \mathrm{kg}^{-1}\right)$ & & & & & \\
Transplanting (2001-02) & $7.89 \mathrm{a}$ & $5.23 \mathrm{~b}$ & $4.95 \mathrm{~b}$ & $4.88 \mathrm{~b}$ & $4.54 \mathrm{~b}$ \\
Flowering (2001-02) & $4.67 \mathrm{a}$ & $4.29 \mathrm{a}$ & $3.84 \mathrm{a}$ & $4.04 \mathrm{a}$ & $3.98 \mathrm{a}$ \\
Transplanting (2002-03) & $8.23 \mathrm{a}$ & $6.42 \mathrm{ab}$ & $5.15 \mathrm{bc}$ & $5.28 \mathrm{bc}$ & $4.89 \mathrm{c}$ \\
Flowering (2002-03) & $5.13 \mathrm{a}$ & $4.66 \mathrm{ab}$ & $4.78 \mathrm{ab}$ & $5.06 \mathrm{a}$ & $4.29 \mathrm{~b}$ \\
Total N (\%) & & & & & \\
Transplanting (2001-02) & $0.197 \mathrm{a}$ & $0.182 \mathrm{~b}$ & $0.167 \mathrm{c}$ & $0.155 \mathrm{c}$ & $0.136 \mathrm{~d}$ \\
Flowering (2001-02) & $0.242 \mathrm{a}$ & $0.227 \mathrm{a}$ & $0.213 \mathrm{a}$ & $0.217 \mathrm{a}$ & $0.160 \mathrm{~b}$ \\
Transplanting (2002-03) & $0.203 \mathrm{a}$ & $0.198 \mathrm{a}$ & $0.186 \mathrm{a}$ & $0.149 \mathrm{~b}$ & $0.126 \mathrm{~b}$ \\
Flowering (2002-03) & $0.236 \mathrm{a}$ & $0.214 \mathrm{a}$ & $0.208 \mathrm{a}$ & $0.214 \mathrm{a}$ & $0.146 \mathrm{~b}$ \\
\hline
\end{tabular}

${ }^{2}$ Values within a row followed by the same letter are not significantly different $(p \leq 0.05, \mathrm{n}=20)$, Duncan's multiple range test.

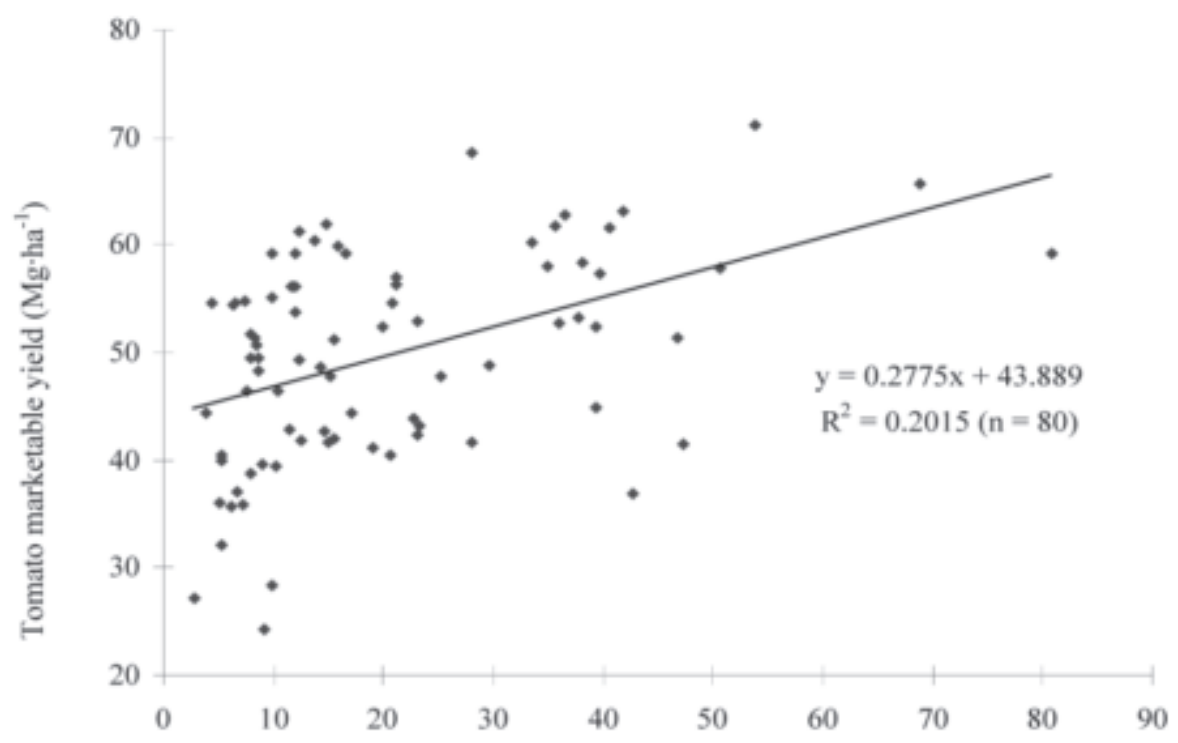

Fig. 1. Correlations between soil $\mathrm{NO}_{3}-\mathrm{N}$ concentrations at tomato flowering and marketable yields of tomatoes.
$\mathrm{Cu}$ concentrations between $-5 \mathrm{kPa},-20 \mathrm{kPa}$ and $-30 \mathrm{kPa}$ treatments, nor between the -5 $\mathrm{kPa}$ and $-10 \mathrm{kPa}$ treatments (Table 7).

Tomato leaf tissue analysis data at flowering showed that tissue $\mathrm{N}$ was increased by treatments of sunn hemp and cowpea, which resulted in a lower $\mathrm{C}$ to $\mathrm{N}$ ratio compared to the fallow. Importantly the data also show that the lowest irrigation rate used, $-30 \mathrm{kPa}$, significantly increased the $\mathrm{N}$ concentration and decreased the $\mathrm{C}$ to $\mathrm{N}$ ratio in tomato leaf tissue (Table 8).

Influence of irrigation rates on fruit titratable acid and sugar contents. Irrigation rates affected the synthesis and accumulation of tomato fruit sugars and acids (Fig. 3). Acid content increased with increasing irrigation rates, while sugar content was highest at the lowest irrigation rate and decreased with increasing application of irrigation water. These relationships are described by the following equations: fruit sugar $(\%)=6.54+0.61$ rate $_{\text {.r. }}$ $\times 0.15$ rate $^{2}\left(R^{2}=0.537^{* *}, \mathrm{n}=20\right)$ and fruit acidity $(\%)=6.5514$ rate $_{\text {irr. }}{ }^{0.0549}\left(R^{2}=0.429^{* *}\right.$, $\mathrm{n}=20)$.

\section{Discussion}

Summer cover crops, such as sunn hemp, cowpea, and velvetbean, can produce much larger quantities of biomass than sorghum sudangrass. The legumes accumulated 2.3 to 3.1 times more $\mathrm{N}$ than sorghum sudangrass and they potentially contributed much more $\mathrm{N}$ to the subsequent tomato crop than did the sorghum sudangrass. In 2002-03 when cowpea produced slightly less biomass than sorghum sudangrass, cowpea still accumulated more than twice as much $\mathrm{N}$ as sorghum sudangrass.

An advantage of summer cover crops is that they can effectively reduce the leaching of soil water and of nutrients. In this regard Wang et al. (2005) determined that the reduction in leachate volume as a percentage of the water applied was $90.8 \%$ by sunn hemp, $71.3 \%$ by sorghum sudangrass, $66.8 \%$ by cowpea, $55.0 \%$ by velvetbean, and $43.7 \%$ by fallow. Based on the same amount of nutrients applied as fertilizer, sunn hemp retained $94 \%$ of soil total $\mathrm{N}$ and $83 \%$ of inorganic $\mathrm{P}$, while velvetbean retained $85 \%$ of soil total $\mathrm{N}$ and $33 \%$ of inorganic $\mathrm{P}$ (Wang et al., 2005). Improvements of tomato yield and quality in the present study appear to be due to conservation of soil water and nutrients, and the large amounts of leguminous cover crop biomass containing high concentrations of nutrients. Legume cover crops, such as sunn hemp, cowpea and velvetbean, provide high quality residues in large part because of their high N contents (Fox et al., 1990; Frankenberger and Abdelmagid, 1985). The contributions of legumes to soil physical and chemical properties, improved soil microbial activity (Swift et al., 1979), and enhanced crop yields have been characterized (Abdul-Baki, 1997; Abdul-Baki et al., 1996; Ibewiro et al., 2000; Teasdale and Wang et al., 2003).

Velvetbean produced higher amounts of biomass and accumulated more $\mathrm{N}$, than cowpea, yet tomato marketable yields in the velvetbean treatment were not commensu- 

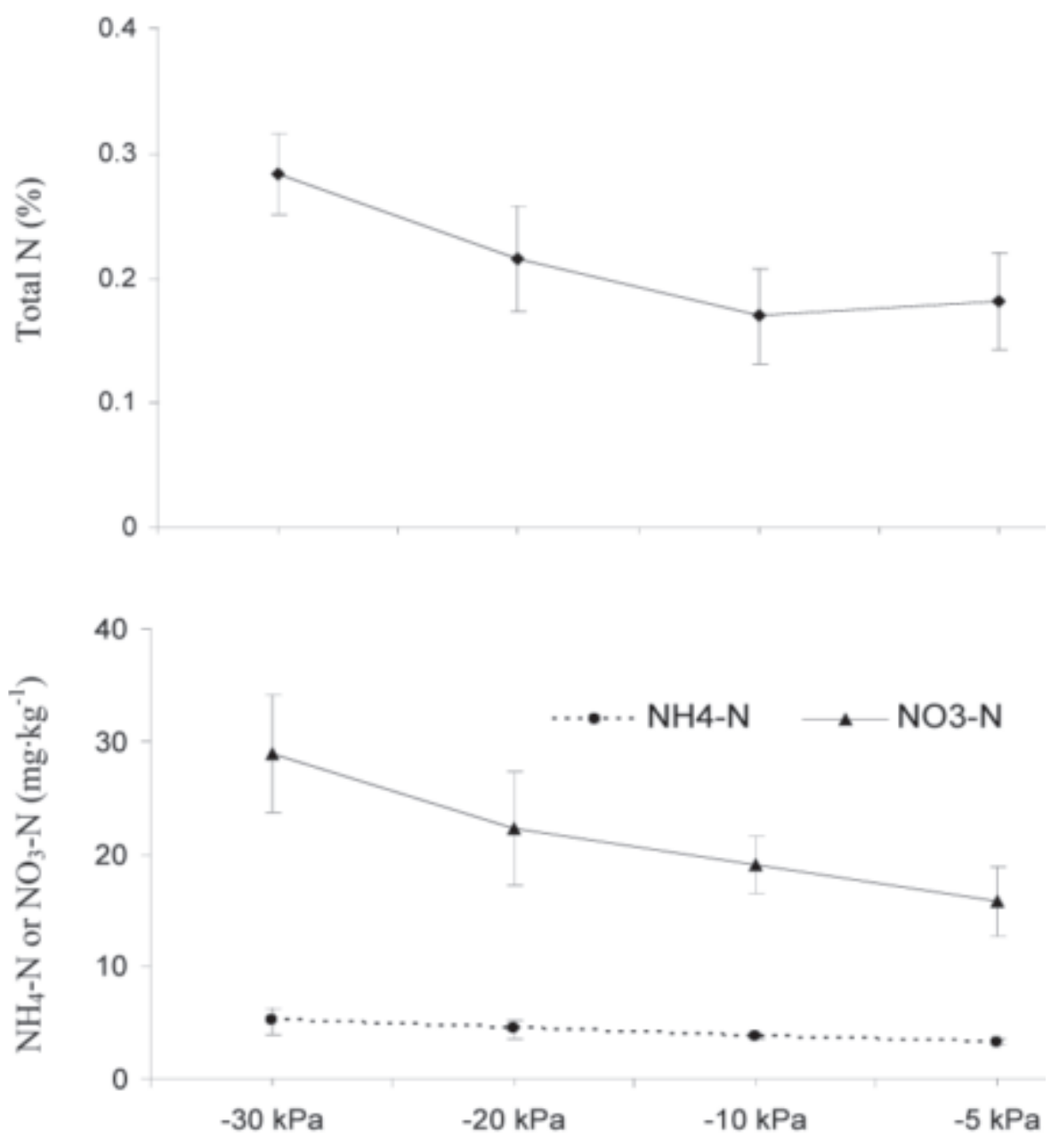

\section{Irrigation rate}

Fig. 2. Concentrations of soil total $\mathrm{N}$ (upper panel), and of soil $\mathrm{NH}_{4}-\mathrm{N}$ and $\mathrm{NO}_{3}-\mathrm{N}$ (lower panel) during tomato flowering at the irrigation rates: $-30,-20,-10$, and $-5 \mathrm{kPa}$, respectively. Each vertical bar represents the standard error of the mean.

rate with the $\mathrm{N}$ content accumulated. The velvetbean treatment produced significantly lower tomato marketable yields than did the cowpea in the 1 st harvest of both years. This failure of the velvetbean treatment to produce high tomato yields might be caused by an allelopathic effect of velvetbean residues on tomato plants. L-dopa, which has allelopathic effects on various species of weeds, has been shown to be present in velvetbean tissues (Fujii, 2000). Moreover, Caamal-Maldonado et al. produced in 2001-02 than in 2002-03. Seeding of the cover crops occurred on 9 May 2001-02 when day lengths were increasing and on 26 July 2002-03 when day lengths were decreasing. In the tropical legumes used in this study long day lengths promote vegetative growth, while short day lengths promote reproduction. Cowpea yielded $70 \%$ less biomass in the year 2002-03 than in 2001-02, this was because it was sown just once in 2002-03, rather than twice as in 2001-02. In 2002-03 the quantity of cowpea biomass was not significantly different from that of sorghum sudangrass, yet the $\mathrm{N}$ content of cowpea was still double that of sorghum sudangrass because of the high concentration of $\mathrm{N}$ in cowpea. The effect of mowing the first cowpea crops and immediately reseeding in 2001-02 was the production of 3.25 -fold the above-ground biomass compared to one seeding delayed seeding in 2002-03, in which only one crop of cowpea was produced. Nevertheless, the tomato yield data indicate that some beneficial effects of cowpea residues were carried over from 2001-02 to 2002-03.

The elevated concentrations of soil nutrients, especially $\mathrm{NO}_{3}-\mathrm{N}$ and total $\mathrm{N}$, at tomato transplanting and flowering indicate that leguminous summer cover crops, especially sunn hemp and cowpea, can make substantial contributions to improved tomato yield and quality. In this experiment, soil $\mathrm{NO}_{3}-\mathrm{N}$ concentrations at tomato flowering were closely correlated with tomato marketable yields.

Tomato fruit usually are harvested at least three times during a growing season in this environment. Often tomato fruit from the first harvest commands the highest price because these tomatoes usually can be on the market by mid-December or January. The enhanced production of extra-large fruit at the first harvest due to sunn hemp and cowpea treatments is important to growers seeking an elevated price from early production. Enhanced tomato yields at the first harvest due to cover crop treatments have been observed previously (Li et al., 1999; Wang et al., 2002a). Yet in another study (Wang et al., 2003) the sunn hemp treatment produced the highest tomato yield at the second harvest in comparison to fallow.

Reducing production costs is a vitally important for the survival of the winter fresh tomato market industry in the U.S. Some leguminous summer cover crops, especially sunn hemp and cowpea, can reliably reduce costs related to fertilization since they effectively retain soil nutrients, as well as produce

Table 7. Contents of some nutrients in soil as influenced by various cover crops and different irrigation rates.

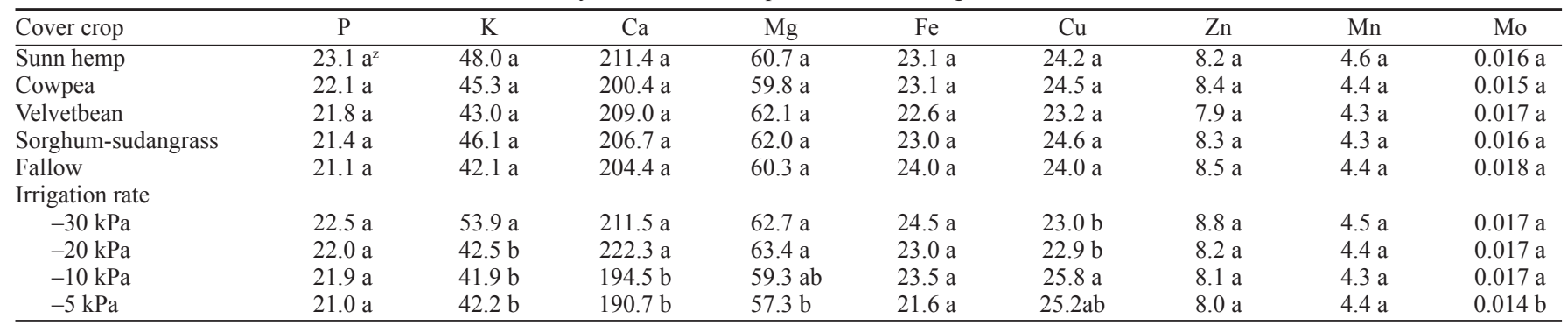

${ }^{2}$ Values within a column followed by the same letter for either cover crop or irrigation rate are not significantly different $(p \leq 0.05, \mathrm{n}=20$ for cover crops and $\mathrm{n}$ $=16$ for irrigation rates)

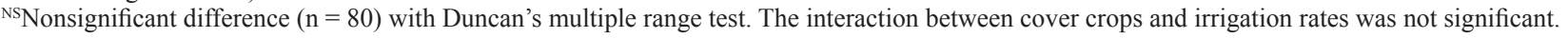


Table 8. Tomato leaf $\mathrm{N}$ and $\mathrm{C}$ concentrations and $\mathrm{C}$ to $\mathrm{N}$ ratios during flowering.

\begin{tabular}{lccc}
\hline Cover crop & $\mathrm{N}$ & $\mathrm{C}$ & $\mathrm{C}$ to N ratio \\
\hline Sunn hemp & $5.25 \mathrm{a}^{\mathrm{z}}$ & $38.3 \mathrm{a}$ & $7.30 \mathrm{~b}$ \\
Cowpea & $5.15 \mathrm{a}$ & $38.3 \mathrm{a}$ & $7.44 \mathrm{~b}$ \\
Velvetbean & $5.09 \mathrm{ab}$ & $38.1 \mathrm{a}$ & $7.49 \mathrm{~b}$ \\
Sorghum sudangrass & $5.04 \mathrm{ab}$ & $37.8 \mathrm{a}$ & $7.50 \mathrm{~b}$ \\
Fallow & $4.75 \mathrm{~b}$ & $37.8 \mathrm{a}$ & $7.96 \mathrm{a}$ \\
Irrigation rate & & & $7.32 \mathrm{~b}$ \\
$\quad-30 \mathrm{kPa}$ & $5.23 \mathrm{a}$ & $38.3 \mathrm{a}$ & $7.51 \mathrm{ab}$ \\
$\quad-20 \mathrm{kPa}$ & $5.10 \mathrm{~b}$ & $38.3 \mathrm{a}$ & $7.43 \mathrm{~b}$ \\
$\quad-10 \mathrm{kPa}$ & $5.10 \mathrm{~b}$ & $37.9 \mathrm{a}$ & $9.04 \mathrm{a}$ \\
\hline
\end{tabular}

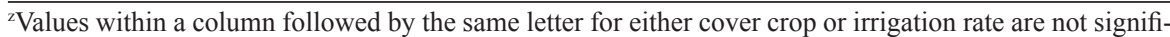
cantly different ( $p \leq 0.05, \mathrm{n}=20$ for cover crops and $\mathrm{n}=16$ for irrigation rates).

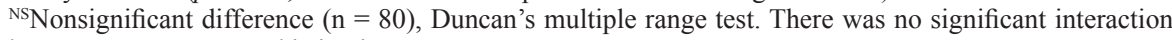
between cover crops and irrigation rates.

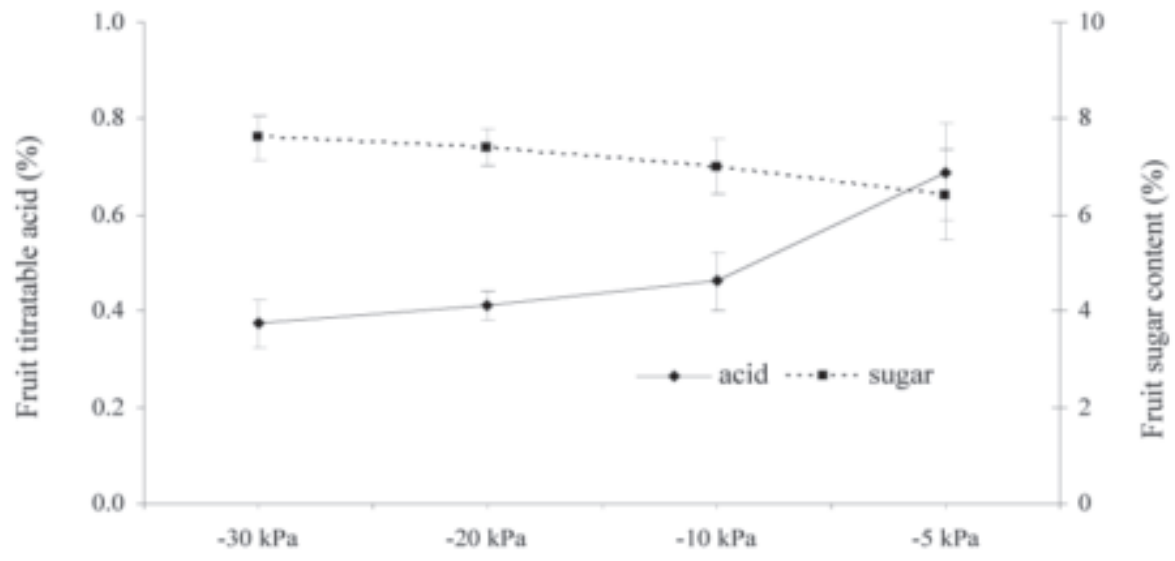

Irrigation rate

Fig. 3. Titratable acid and sugar contents in tomatoes as affected by irrigation rates. Each vertical bar represents the standard error of the mean.

large quantities of biomass and return them to the soil. This high quality biomass improves tomato yield and quality, and can also reduce synthetic fertilizer use. Sunn hemp can also effectively reduce populations of plant-parasitic nematodes, and this action may also benefit subsequent crops (Wang et al., 2002b).

The standard practice in the subtropical region is to initiate irrigation at tensiometer readings of about $-5 \mathrm{kPa}$. This results in over-watering and decreases tomato yields and quality (Li et al., 1998; Olczyk et al., 2000; Wang et al., 2002a). Munoz-Carpena et al. (2003) suggest that $-15 \mathrm{kPa}$ as the set point rather than $-10 \mathrm{kPa}$ perform the best for tomato production, which can save $73 \%$ of irrigation water based on their automatic soil moisture control system, but they did not evaluate lower rates. This study indicates that delaying irrigation until the tensiometer reading reaches $-30 \mathrm{kPa}$ saves water, reduces nutrient losses via leaching, and protects against soil pathogens that thrive in wet soils.

The quantities of water applied at the various irrigation rates in 2002-03 were substantially less than in the corresponding treatments in 2001-02. In 2002-03 tomato seedlings were transplanted on 9 Dec., which was $47 \mathrm{~d}$ later in the year than in 2001-02 when transplanting was done on 23 Oct. By early December 2002, the average temperatures in the region had declined substantially, evapotranspiration had become depressed, and the tomato plant's need for irrigation had been reduced sharply. In both years the relative amounts of irrigation water saved by irrigating at $-30 \mathrm{kPa}$, instead of $-5 \mathrm{kPa}$, were similar, about $85 \%$. In the subtropical region of Florida most tomato growers defer planting toward the end of hurricane season (about 30 Nov.) when temperatures and associated evapotraspiration rates have declined. The growers who are willing to risk early season planting to take advantage of the stronger early winter market demand would benefit by irrigating at $-30 \mathrm{kPa}$. This would save water and fertilizer and produce higher marketable yields and larger fruits.

Regardless of the transplanting date, controlling irrigation at $-30 \mathrm{kPa}$ can significantly improve yields of total marketable, extra-large and large tomatoes. Such yield increases probably derive from the conservation of soil In addition, reduced irrigation rates correlated with changes in the pattern of carbohydrate metabolism in tomato fruits, e.g., as the irrigation rates declined, the fruit titratable acidity decreased and the sugar levels increased.

The results of this study indicate that growing and incorporating summer cover crops sunn hemp and cowpea, into the tomato production system in a subtropical region, together with a substantial reduction in irrigation rates, can improve soil fertility, conserves soil water and nutrients and substantially increase tomato yield and quality. nutrients, especially soil total $\mathrm{N}$ and $\mathrm{NO}_{3}-\mathrm{N}$.

\section{Literature Cited}

Abdul-Baki, A.A., H.H. Bryan, G. Zinati, W. Klassen, M. Codallo, and N. Heckert. 2001. Biomass, yield and flower production in sunn hemp: Effect of cutting the main stem. J. Veg. Crop Prod. 7:83-104.

Abdul-Baki,A.A., J.R. Strommel, A.E. Watada, J.R. Teasdale, and R.D. Morse. 1996. Hairy vetch mulch favorably impacts yield of processing tomatoes. HortScience 31:338-340.

Abdul-Baki, A.A., J.R. Teasdale, and R.F. Korcak. 1997. Nitrogen requirements of fresh-market tomatoes on hairy vetch and black polyethylene mulch. HortScience 32:217-221.

Brandi-Dohrn, F.M., R.P. Dick, M. Hess, S.M. Kauffman, D.D. Hemphill, Jr., and J.S. Selker. 1997. Nitrate leaching under a cereal rye cover crop. J. Environ. Qual. 26:181-188.

Brown, R. 2000. Handling regulations. Fla. Tomato Comm. Reg. Bul. 2. p. 4.

Caamal-Maldonado, J.A., J.J. Jimenez-Osornio, A. Torres-Barragan, and A.L. Anaya. 2001. The use allelopathic legume cover and mulch species for weed control in cropping systems. Agron. J. 93:27-36.

Campbell, C.A., R. DeJong, and P.R. Zentner. 1984. Effect of cropping, summer fallow, and fertilizer nitrogen on nitrate nitrogen lost by leaching on a brown Chernozemic loam. Can. J. Soil Sci. 64:61-74.

Campbell, C.A., G.P. Lafond, R.P. Zentner, and W. Jame. 1994. Nitrate leaching in an Udic Haploboroll as influenced by fertilization and legumes. J. Environ. Qual. 23:195-201.

Dorsch, R.K.S., A.J. McMichael, P.A. Bighurst, and K.J. Dyer. 1984. Congenital malformations and maternal drinking water supply in rural South Australia: A case study. Amer. J. Epidemiol. 119:473-486.

Duever, M.J., J.F. Meeder, L.C. Meeder, and J.M. McCullom. 1994. The climate of south Florida and its role in shaping the Everglades ecosystem, p. 225-248. In: S.M. Davis, and J.C. Ogden (eds.). Everglades - The ecosystem and its restoration. St. Lucie Press, Delray Beach, Fla.

Fox, R.H., R.J.K. Myers, and I. Vallis. 1990. The nitrogen mineralization rate of legume residues in soil as influenced by their polyphenol lignin and nitrogen contents. Plant Soil 129:251-259.

Frankenberger, W.T. and H.M. Abdelmagid. 1985 Kinetic parameters of nitrogen mineralization rate of leguminous crops incorporated into soil. Plant Soil 87:257-271.

Fujii, Y. 2000. Significance of allelopathy and its application to agriculture. Farming Japan 34:41-43.

Hallberg, G.R. 1989. Nitrate in groundwater in the United States, p. 35-75. In: R.F. Follett (ed.). Nitrogen management and groundwater protection. Elsevier, Amsterdam.

Hanlon, E.A.B., B. Schaffer, M. Ozores-Hampton, and H.H. Bryan. 1996. Ammonium bicarbonate-DTPA extraction of elements from wasteamended calcareous soil. Commun. Soil Sci. Plant Anal. 27:2321-2335.

Ibewiro, B., N. Sanginga, B. Vanlauwe, and R. Merckx. 2000. Nitrogen contributions from decomposition cover crop residues to maize in a tropical derived savanna. Nutrient Cycl. Agroecosys. 57:131-140.

Jolivet, C., D. Arrouays, and M. Bernoux. 1998. Comparison between analytical methods for organic carbon and organic matter determination in sandy spodosols of France. Commun. Soil Sci. Plant Anal. 29:2227-2233.

Kadir, J.B., R. Charudattan, W.H. Stall, and B.J. Brecke. 2000. Field efficacy of Dactylaria hig- 
ginsii as a bioherbicide for the control of purple nutsedge (Cyperus rotundus). Weed Technol. 14:1-6.

Karlen, D.L. and J.W. Doran. 1991. Cover crop management effects on soybean and corn growth and nitrogen dynamics in an on-farm study. Am. J. Alt. Agr. 6:71-82.

Li, Y., H.H. Bryan, R. Rao, N. Heckert, and T. Olczyk. 1999. Summer cover crops for tomato production in south Florida, p. 18-21. In: C.S. Vavrina (ed.). Florida Tomato Institute proceedings: Citrus and vegetable. Univ. Florida.

Li, Y., R. Rao, H.H. Bryan, and T. Olczyk. 1998. Optimized irrigation schedule to conserve water and reduce nutrient leaching for tomatoes grown on a calcareous gravelly soil. Proc. Fla. State Hort. Soc. 111:58-61.

Linville, K.W. and G.E. Smith. 1971. Nitrate content of soil cores from corn plots after repeated nitrogen fertilization. Soil Sci. 112:249-255.

Maynard, D.N. and S.M. Olson. 2000. Vegetable production guide for Florida. Univ. Fla. Citrus Veg. 247.

Muñoz-Carpena, R., H.H. Bryan, W. Klassen, and
M. Dukes. 2003. Automatic soil moisture-based drip irrigation for improving tomato production. Proc. Fla. State Hort. Soc. 116:80-85.

Nielsen, E.G. and L.K. Lee. 1987. The management and costs of groundwater contamination from agricultural chemicals: A national perspective. USDA Econ. Res. Serv. Agr. Econ. Rpt. 576.

Olczyk, T., R. Regalado, Y. Li, and R. Jordan. 2000. Usefulness of tensiometers for scheduling irrigation for tomatoes grown on rocky, calcareous soils in southern Florida. Proc. Fla. State Hort. Soc. 113:239-242.

SAS Institute. 1999. SAS. version 8.1. SAS, Cary, N.C.

Schulte, E.E. and B.G. Hopkins. 1996. Estimation of soil organic matter by weight loss-on-ignition, p. 21-31. In: F.R. Magdoff (ed.). Soil organic matter: Analysis and interpretation. Soil. Sci. Soc. Amer. Spec. Publ. 46.

Stevens, M., A. Allen, A. Kader, and M. Albright. 1979. Potential for increasing tomato flavor via increased sugar and acid content. J. Amer. Soc. Hort. Sci. 104:40-42.

Swift, M.J., O.W. Heal, and J.M. Anderson. 1979.
Decomposition in terrestrial ecosystems, p. 372. Blackwell Scientific, Oxford.

Teasdale, J.R. and A.A. Abdul-Baki. 1997. Growth analysis of tomatoes in black polyethylene and hairy vetch production systems. HortScience 32:659-663.

Wang, Q., H.H. Bryan, W. Klassen, Y. Li, M. Codallo, and A.A. Abdul-Baki. 2002a Improved tomato production with summer cover crops and reduced irrigation rates. Proc. Fla. State Hort. Soc. 115:202-207.

Wang, Q., W. Klassen, A.A. Abdul-Baki, H.H. Bryan, and Y. Li. 2002b. Influence of summer cover crops on soil nematodes in a tomato field. Soil Crop Sci. Soc. Fla. Proc. 62:86-91.

Wang, Q., W. Klassen, H.H. Bryan, Y. Li, and A.A. Abdul-Baki. 2003. Influence of summer cover crops on growth and yield of a subsequent tomato crop in south Florida. Proc. Fla. State Hort. Soc. 116:140-143.

Wang, Q., Y. Li, and W. Klassen. 2005. Influence of summer cover crops on conservation of soil water and nutrients in a subtropical area. J. Soil Water Conserv. 60:58-63. 